\title{
Evaluation of total phenols and antibacterial activity of certain drug plants against some bacterial species
}

\author{
Manisha G. Ranpariya ${ }^{1}$ and Rita S. Chudasama ${ }^{2 *}$ \\ ${ }^{1}$ Microbiology Department, Shree M. and N. Virani Science College,Rajkot-360 005 (Gujarat), INDIA \\ ${ }^{2}$ Biology Department, Gyanyagna College of Science and Management, Rajkot-360 005(Gujarat), INDIA \\ *Corresponding author. E-mail: chudasamarita@yahoo.com
}

Abstract :The present paper deals with antimicrobial activity of Glycyrrhiza glabra, Tinospora cordifolia, Tribulus terrestris, Thevetia peruviana, Adhatoda vasica, Vitex negungo, Apium graveolens and, Annona squamosa. It was studied against Bacillus cereus, Staphylococcus aureus, Salmonella typhy B (STB), Shigella dysenteriae using solvent (methanol and petroleum ether) extraction method. Methanol extract of all eight plants showed prominent inhibitory activity against $S$. dysenteriae and STB while G. glabra, V. negundo, and T. peruviana showed maximum zone of inhibition against four studied bacterial species. These results suggest that methanol extract is more effective than petroleum ether for the antimicrobial activity. Further total phenols were estimated and antibacterial activity of these plants in relation to total phenolic content is discussed.

Keywords: Antibacterial activity, Methanol extract, Petroleum ether extract, Total phenols

\section{INTRODUCTION}

The use of the plants, plant extracts and pure compounds isolated from natural sources provided the foundation to modern pharmaceutical compounds. The interest in the study of medicinal plants as a source of pharmacologically active compounds has increased worldwide. Several studies indicated that medicinal plants contain substances like peptide, unsaturated long chain fatty acids, aldehydes, alkaloids, essential oils, phenols and water or ethanol soluble compounds. These compounds are potentially significant in therapeutic applications against human and animal pathogens, including bacteria, fungi and viruses (Iwu et al., 1999 and Khan et al., 2003).

It is recognized that, in some developing countries plants are the main medicinal source to treat infectious diseases (Al-Bayati and Al-Mola, 2008). Contrary to synthetic drugs, antimicrobials of plant origin usually are not associated with many side effects and have an enormous anti-infective potential in numerous infectious diseases. Detailed research on the chemistry and pharmacology of products of plant origin are much essential and this may eventually lead to the discovery of medicine that can be used in the treatment of several diseases. Studies can show that the toxic effects of radiations and chemotherapy in cancer treatment could be reduced by Ayurvedic medications (Joy et al., 1998). Based on World Health Organization (WHO) reports, more than $80 \%$ of the World population relies on traditional medicine for their primary healthcare needs (Duraipandiyan et al., 2006).
Plants are rich in a wide variety of secondary metabolites such as tannins, terpenoides, alkaloids and flavonoides which have been found in vitro to have antimicrobial properties (Cowan, 1999). Phenolic compounds represent a large group of molecules are widely distributed in plant kingdom and main purpose is found to be defensive. Phenolic compounds are characteristic of plants and as a group they are usually found as esters or glycosides rather than as free compounds. Phenolic compounds include signaling molecules, pigments and flavors that can attract or repel, as well as compounds that can protect the plant against insects, fungi, bacteria, and viruses. In the presented work eight plants i.e., Glycyrrhiza glabra (Papilionaceae), Tinospora cordifolia(Menispermaceae), Tribulus terrestris (Zygophyllaceae), Thevetia peruviana (Apocynaceae), Adhatoda vasica (Acanthaceae), Vitex negundo (Verbenaceae), Apium graveolens (Apiaceae), and Annona squamosa (Annonaceae) are selected for total phenolic contents and its antibacterial activity.

\section{MATERIALS AND METHODS}

Test organisms: Four bacterial strains i.e., two gram positive; Bacillus cereus, Staphylococcus aureus, and two gram negative; Salmonella typhy B (STB), Shigella dysenteriae were selected for antimicrobial activity.

Activation of culture and inoculum preparation: Active cultures were prepared by transferring a loop full of cells from the stock culture to autoclaved nutrient broth. The flasks were incubated on shaking condition at $37^{\circ} \mathrm{C}$ for $24 \mathrm{~h}$. Next day activated cultures were used for the study. The inoculum $(0.1 \mathrm{ml})$ was prepared in sterile distilled 
Table 1. Total phenols of plant extracts.

\begin{tabular}{cccc}
\hline No. & Plant name & $\begin{array}{c}\text { mg CGA } \\
\text { equivalent/gm } \\
\text { dry weight }\end{array}$ & $\begin{array}{c}\text { 土Standard } \\
\text { deviation }\end{array}$ \\
\hline 1 & Glycyrrhiza glabra & 2.351079 & 0.071418 \\
2 & Tinospora cordifolia & 1.096583 & 0.18809 \\
3 & Ttribulua terrestris & 1.195504 & 0.142836 \\
4 & Thevetia peruviana & 2.13705 & 0.054447 \\
5 & Aadhatoda vasica & 1.621763 & 0.091924 \\
6 & Vitex negundo & 1.28723 & 0.196576 \\
7 & Apium graveolens & 1.324101 & 0.130815 \\
8 & Annona squamosa & 1.905036 & 0.060104 \\
\hline
\end{tabular}

water $(0.9 \mathrm{ml})$ and $10^{-3}$ dilution was utilized for the crude method. For the agar ditch diffusion method, $0.1 \mathrm{ml}$ of broth was mixed with $20 \mathrm{ml}$ of autoclaved Mueller-Hinton agar medium.

Collection of plants: Eight plants with their selected parts i.e.; Glycyrrhiza glabra (wood), Tinospora cordifolia (tender), Tribulus terrestris (fruit), Thevetia peruviana (leaf), Adhatoda vasica (leaf), Vitex negundo (leaf), Apium graveolens (seed), Annona squamosa (seed) were collected from the Junagadh area, Gujarat. The application of any plant as a drug depends on the accumulation of active ingredients in a particular part. Based on literature survey (Khare, 2007) from these plants, the different parts with medicinal value (as mentioned above with their name) were separated and washed with tap water. They were surface sterilized with $0.1 \% \mathrm{HgCl}_{2}$ followed by three washes of distilled water and kept for air drying.

Preparation of plant extract: The air dried parts cut into small pieces and homogenized in a mechanical mortar to fine powder. These powders were used for preparation of solvent extracts. Three grams of dry powder weighed and mixed in $30 \mathrm{ml}$ methanol and petroleum ether respectively and kept for 3 days at $37^{\circ} \mathrm{C}$ on shaking condition. The plants extracts were centrifuged at 5000 rpm and residues washed twice with respective solvents. The supernatants were kept for evaporation in dark condition. Dried evaporated extracts were dissolved in Dimethyl sulfoxide (DMSO) and final volume $5 \mathrm{ml}$ was prepared $(60 \mathrm{mg} / 0.1 \mathrm{ml})$. All extract were stored at $4{ }^{\circ} \mathrm{C}$ and used for further studies.

Antibacterial activity: These eight plants were first screened by crude extract method for its antimicrobial property against the selected bacterial strains. Later on their antibacterial activity was studied by agar ditch diffusion method using solvent extracts. In this method $0.1 \mathrm{ml}$ of bacterial culture was inoculated in $20 \mathrm{ml}$ of autoclaved Mueller-Hinton agar. This is mixed properly, poured in sterile petri plate and allowed for solidification. After solidification a ditch $(6 \mathrm{~mm})$ was made in the centre of plate with the help of a sterile cup borer. Hundred $\mu 1$ test extract was introduced into the ditch and the plates were incubated overnight at $37^{\circ} \mathrm{C} 24 \mathrm{~h}$. Next day results were recorded by measuring the zone of inhibition.

Extraction of phenolic compound from the plants: Two grams of dry powder was taken and to this $10 \mathrm{ml}$ of $80 \%$ ethanol was added. The mixer was kept in dark for $24 \mathrm{~h}$ in shaking condition. Next day the extracts were centrifuged at $3000 \mathrm{rpm}$ for $15 \mathrm{~min}$. The supernatant was collected in petri plate and allowed for evaporation. The remaining dry residue was dissolved in sterile distilled water and final volume $(5 \mathrm{ml})$ was prepared.

Assay of total phenols: The concentration of total phenols was determined with Folin-Ciocalteu reagent following the colorimetric method (Folin and Ciocalteu, 1927). Measurements were carried out in triplicate. A calibration curve of chlorogenic acid in a range of 5-50

Table 2. Antibacterial activity of methanol extracts of Glycyrrhiza glabra, Tinospora cordifolia, Tribulus terrestris, Thevetia peruviana, Adhatoda vasica, Vitexnegundo, Apium graveolens, Annona squamosa against Bacillus cereus, Staphylococcus aureus, Salmonella typhy B (STB), and Shigella dysenteriae.

\begin{tabular}{|c|c|c|c|c|c|}
\hline \multirow[b]{2}{*}{ No. } & \multirow[b]{2}{*}{ Plant name } & \multirow[b]{2}{*}{ Bacillus cereus } & \multicolumn{2}{|c|}{ Zone of inhibition (mm) } & \multirow[b]{2}{*}{$\begin{array}{c}\text { Shigella } \\
\text { dysenteriae }\end{array}$} \\
\hline & & & $\begin{array}{c}\text { Staphylococcus } \\
\text { aureus }\end{array}$ & $\begin{array}{c}\text { Salmonella typhy } \\
\text { B (STB) }\end{array}$ & \\
\hline 1 & Glycyrrhiza glabra & $18+1.0$ & $18+1.7$ & $23+1.0$ & $13+2.5$ \\
\hline 2 & Tinospora cordifolia & $13 \pm 2.0$ & - & $14 \pm 1.2$ & $16 \pm 0.5$ \\
\hline 3 & Ttribulua terrestris & $14 \pm 2.0$ & - & $17 \pm 2.6$ & $11 \pm 0.5$ \\
\hline 4 & Thevetia peruviana & $17 \pm 1.5$ & $13 \pm 1.0$ & $13 \pm 1.0$ & $17 \pm 2.6$ \\
\hline 5 & Aadhatoda vasica & $15 \pm 1.0$ & - & $14 \pm 0.5$ & $21 \pm 0.1$ \\
\hline 6 & Vitex negundo & $13+0.5$ & $16+0.5$ & $23+3.0$ & $15+1.5$ \\
\hline 7 & Apium graveolens & - & - & - & $11 \pm 1.1$ \\
\hline 8 & Annona squamosa & - & - & $13.3 \pm 2.0$ & $13 \pm 0$ \\
\hline
\end{tabular}


Table 3. Antibacterial activity of petroleum ether extracts of Glycyrrhiza glabra, Tinospora cordifolia, Tribulus terrestris, Thevetia peruviana, Adhatoda vasica, Vitexnegundo, Apium graveolens, Annona squamosa againstBacillus cereus, Staphylococcus aureus, Salmonella typhy B (STB), and Shigella dysenteriae.

\begin{tabular}{llcccc}
\hline No. & Plant name & $\begin{array}{c}\text { Bacillus } \\
\text { cereus }\end{array}$ & $\begin{array}{c}\text { Staphylococcus } \\
\text { aureus }\end{array}$ & $\begin{array}{c}\text { Salmonella typhy } \boldsymbol{B} \\
\text { (STB) }\end{array}$ & $\begin{array}{c}\text { Shigella } \\
\text { dysenteriae }\end{array}$ \\
\hline 1 & Glycyrrhiza glabra & $15 \pm 1.5$ & $21 \pm 1.5$ & $14 \pm 1.5$ & $12 \pm 1.0$ \\
2 & Tinospora cordifolia & $10 \pm 0.5$ & $15 \pm 1.0$ & $14 \pm 0.5$ & $10 \pm 0.5$ \\
3 & Ttribulua terrestris & - & $10 \pm 0.5$ & $12 \pm 0.5$ & $12 \pm 0$ \\
4 & Thevetia peruviana & - & $13.6+1.5$ & $11+1.0$ & $17.3+3.5$ \\
5 & Aadhatoda vasica & $16 \pm 0.5$ & $-12 \pm 1.5$ & - \\
6 & Vitex negundo & $15 \pm 1.0$ & $12 \pm 1.0$ & $15 \pm 0.5$ & $12 \pm 1.5$ \\
7 & Apium gr aveolens & - & $15.3+2.8$ & $15+2.4$ & - \\
8 & Annona squamosa & - & & & $15.6+1.6$ \\
\hline
\end{tabular}

$\mu \mathrm{g} / \mathrm{ml}$ was prepared (Figure 1). The levels of total phenols were expressed as milligrams of chlorogenic acid equivalents per gram of dry weight ( $\mathrm{mg} \mathrm{CGA} \mathrm{g}^{-1} \mathrm{DW}$ ).

\section{RESULTS AND DISCUSSION}

The use of plant extracts and phytochemicals, with established antimicrobial properties, could be of great significance in preventive and/or therapeutic approaches. In the present study, the eight plants were initially screened by crude extract method against two gram positive and gram negative bacteria for its antimicrobial property. Further their precise antimicrobial activity was tested by agar well diffusion method using different solvent extracts. This method showed significant reduction in bacterial growth in terms of zone of inhibition around the ditch. The most important exhibited antimicrobial compounds of plants are alkoloids, flavonoids, tannins and phenolic compounds (Ates and Erdogrul, 2003; Duraipandiyan et al., 2006). Phenolic compounds represent a large group of molecules with a variety of functions in plant growth, development, and defense (Duraipandiyan et al., 2006). In this study the total phenolic content from the selected medicinal plants was estimated. The probable role of total phenols in antibacterial activity was analyzed. Among the all selected plants G. glabra showed the maximum amount of total phenols followed by $T$. peruviana and A. squamosa (Table 1). The antibacterial activity of methanol and petroleum ether extract of these plants is presented in Table 2 and 3.

It was observed that the selected eight plants possessed relatively antibacterial activity against gram positive and gram negative bacteria. The methanol extract of $V$. negundo and G. glabra showed maximum zone of inhibition against Salmonella typhy B (STB) while petroleum ether extract of $A$. graveolens showed maximum zone of inhibition against $(S T B)$. However methanol extract of all plants except $A$. graveolens showed inhibitory activity against $S T B$.

Staphylococcus aureus was highly inhibited by petroleum ether extract of G. glabra and A. graveolens followed by A. squamosa, T. cordifolia, V. negundo and T.terrestris. The presence of antimicrobial substance in the higher plants is well established. In G. glabra phenolic alcoholic class of compounds (flavonoids) are present which are active against $S$. aureus (Fukai et al., 2002). The present study showed maximum amount of phenolic content in G. glabra amongst the studied plants which may lead to highest antibacterial activity. Methanol extracts of $G$. glabra exhibited potent antimicrobial activity against cariogenic bacterium Streptococcus mutans (Hwang et al., 2004). Antimicrobial activity of G glabra against gram negative bacteria was reported by Shirazi et al. (2007). Previous study revealed that about 100 phenolic compounds have been identified from the Glycyrrhiza species, many of which are isoprenoid substituted phenols (flavonoids). Some of these flavonoids have shown inhibitory activities against bacterial growth (Hsieh and Wu, 2002; Fukai et al., 2004; Jain et al., 2006). Methanol extract of $T$. cordifolia, T. terrestris, A. vasica, A. graveolens and A. squamosa was not showing inhibition against $S$. aureus. Earlier it was demonstrated that ethanolic extracts of the fruit and leaf of Indian $T$. terrestris were active against Escherichia coli and $S$. aureus (Williamson, 2002). However different parts of Turkish and Iranian $T$. terrestris have been reported to have antibacterial activity (Abbasoglu and Tosun, 1994; Kianbakht and Jahaniani, 2003).

In comparison to petroleum ether the methanol extract of all eight plants showed inhibitory activity against 


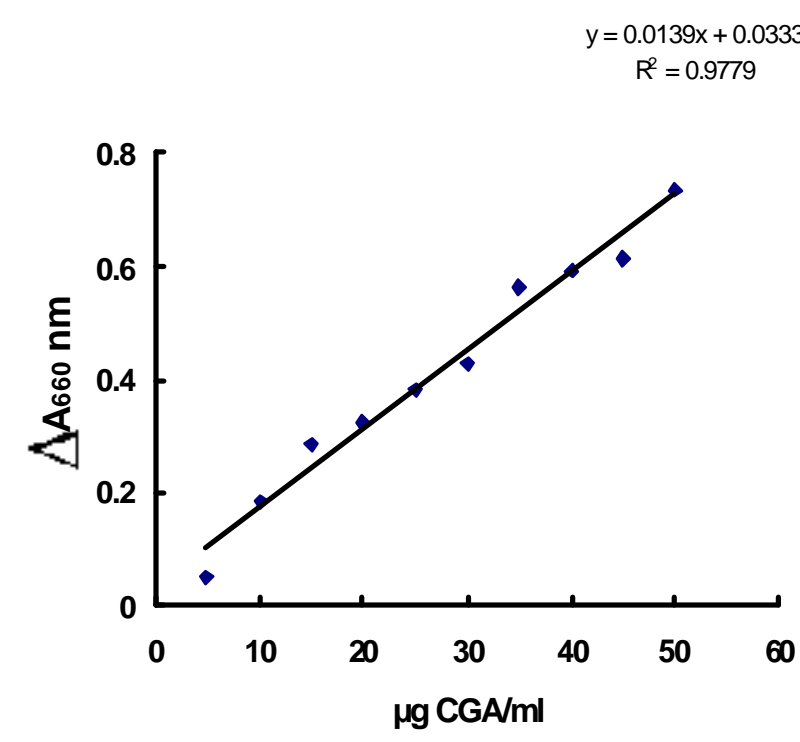

Fig. 1. A calibration curve of chlorogenic acid.

Shigella dysenteriae. S. dysenteriae was highly inhibited by methanol extract of A. vasica followed by $T$. peruviana, T. cordifolia, V. negundo, G. glabra, T. terrestris, and A. graveolens. Both extracts of G. glabra, T. cordifolia, V. negundo and $A$. vasica showed inhibition against $B$. cereus. However the zone of inhibition remained higher by methanol extracts of G. glabra and $T$. cordifolia plants. Methanol extract of T. peruviana showed maximum zone of inhibition against Bacillus cereus and Shigella dysenteriae, while its inhibitory activity was similar to $S$. aureus and $S$. typhy $B$ (Table 2 ). The results showed that the methanol extract of all test plants has more inhibitory effect. This tends to express that the active ingredients of the plant parts may be better extracted with methanol than other solvents (Babu etal., 2007).

The present study revealed that all tested plant extracts were effective against gram negative bacterial species. Instead of both solvent extracts methanol extracts exhibited a higher degree of antimicrobial activity compared to petroleum ether extract. Roberts et al. (1981) demonstrated that the antibacterial activity of methanol extract is due to the presence of phenolic and acidic compounds. Among the studied plants G. glabra and V. negundo with their both extracts remained highly inhibitory against the four selected bacteria. Higher amount of phenolic content of G. glabra, T. peruviana and A. squamosa lead to their antimicrobial property. The antimicrobial activity of phenols is well established (Paupponen et al., 2001 and Pansuria et al., 2006). The antimicrobial activities of naturally occurring phenolics from olives, tea and wine have been widely studied (RuizBarba et al., 1990; Vivas et al., 1997 and Chou et al., 1999). Based on the results, it is concluded that methanolic extracts have great potential as antimicrobial compounds against microorganisms and they can be used in the treatment of infectious diseases caused by the selected microorganisms.

\section{REFERENCES}

Abbasoglu, U. and Tosun, F. (1994). Antimicrobial activity of Tribulus terrestris L. growing in Turkey. Hacettepe Universitesi Eczacilik Fakultesi Dergisi, 14 (2): 81-85.

AL-Bayati, F.A. and AL-Mola, H.F. (2008). Antibacterial and antifungal activities of different parts of Tribulus terrestris L. growing in Iraq. J. Zhejiang Univ. Sci. B, 9(2): 154-159.

Ates, D.A. and Erdogrul, O.T. (2003). Antimicrobial activities of various medicinal and commercial plant extracts. Turk. J. Biol., 27: 157-162.

Babu, S., Satish, S., Mohana, D.C., Raghavendra, M.P. and Raveesha, K.A. (2007). Antibacterial evaluation and phytochemical analysis of some Iranian medicinal plants against plant pathogenic Xanthomonas pathovars. J. Agri. Tech., 3(2): 307-316.

Chou, C.C., Lin, L.L. and Chung, K.T. (1999). Antimicrobial activity of tea as affected by degree of fermentation and manufacturing season. Int. J. Food Microbial., 48: 125-130.

Cowan, M.M. (1999). Plant products as antimicrobial agents. Clinical Microbiol. Rev., 12(4): 564-582.

Duraipandiyan, V., Ayyanar, M. and Ignacimuthu, S. (2006). Antimicrobial activity of some ethnomedicinal plants used by paliyar tribe from Tamil Nadu, India. BMC Complement Med. Altern., 6: 35.

Folin, O. and Ciocalteu, V. (1927). On tyrosine and tryptophan determinations in proteins. J. Biol. Chem., 73: 627-650.

Fukai, T., Oku, Y., Hano, Y. and Terada, S. (2004). Antibacterial activities of hydrophobic 2-arylbenzofurans and an isoflavone against vancomycin-resistant Enterococci and methicillin-resistant Staphylococcus aureus. Planta Med., 70(7): 685-687.

Fukai, T., Marumo, A., Kaitou, K., Kanda, T., Terada, S. and Nomura, T. (2002). Antimicrobial activity of licorice flavonoids against methicillin-resistant Staphylococcus aureus. Fitoterapia, 73(6): 536-539.

Hsieh, T.C. and Wu, J.M. (2002). Mechanism of action of herbal supplements PC-SPES: elucidation of effects of individual herbs of PC-SPES on proliferation and prostate specific gene expression in androgen-dependent LNCaP cells. Int. J. Oncol., 20(3): 583-588.

Hwang, J.K., Shim, J.S. and Chand, J.Y. (2004) Anticariogenic activity of some tropical medicinal plant against Sreptococcus mutant. Fitoterapia, 75: 596-598.

Iwu, M.M., Duncan, A.R. and Okunji, C.O. (1999). New antimicrobials of plant origin. In: J. Janick (Ed.), Prospective on New Crops and New Uses, (pp 457-462), ASHS Press, Alexandria, VA.

Jain, H., Li, C., David, H., Wenyuan, S. and Qing, Y.L. (2006). Antibacterial compounds from Glycyrrhiza uralensis. J. Nat. Prod., 69: 121-124.

Joy, P.P., Thomas, J., Samuel, M. and Skaria, B.P. (1998). Medicinal plants, Kerala Agricultural University, Aromatic and Medicinal Plants Research Station, Kerala, India.

Khan, M., Kibara, M. and Oinoloso, B. (2003). Antibacterial activity of the alkaloidal constituents of the root bark of Eupomatia lourina. Pharmaceut Biol., 41: 277-280. 
Khare, C.P. (2007). Indian Medicinal plants - An illustrated dictionary. Springer Science+BusinessMedia, LLC., 233 Spring Street, New York, NY 10013, USA.

Kianbakht, S. and Jahaniani, F. (2003). Evaluation of antibacterial activity of Tribulus terrestris L. growing in Iran, Iran J. Pharmacol. Therapeut., 2(1): 22-24.

Pansuria, S.H., Chudasama, R.S., Bagatharia, S.B. and Thaker, V.S. (2006). Production of diphenol and monophenol compounds from the leaf callus of Morus alba and studies on their antibacterial properties. Ind. J. Plant Physiol., 11(1): 36-40.

Paupponen, P., Nohynek, L., Meier, C., Kahkonen, M., Heinonen, M., Hopia, A. and Oskman Caldentey, K. M. (2001). Antimicrobial properties of phenolic compounds from berries. J. Appli. Microbiol., 90: 494-507.

Roberts, R.M., Gilbert, J.C., Rodewald, L.B. and Wingrove, A.S. (1981). Modern experimental organic chemistry. $3^{\text {rd }}$ edition. Saunders golden sunburst series, Saunders college (Philadelphia), and Holt- Saunders Japan (Tokyo), pp 495-505. Ruiz-Barba, J.L., Rios-Sanchez, R.M., Fedriani-Iriso, C., Oils, J.M., Rois, J.L. and Jimenez-Diaz, R. (1990). Bacterial effect of phenolic compounds from green olives on Lactobacillus plantarum. Syst. Appli. Microbiol., 13: 199-205.

Shirazi, M.H., Ranjbar, R., Eshraghi, S., Sadeghi, G., Jonaidi, N., Bazzaz, N., Izadi, M. and Sadeghifard, N. (2007). An evaluation of antibacterial activity of Glycyrrhiza glabra extract on the growth of Salmonella, Shigella, and ETEC E.coli. J. Biol. Sci., 7(7): 827-829.

Vivas, N., Lonvaud, F.A. and Glories, Y. (1997). The phenolic constituents of Pinus domestica I. The quantitative analysis of phenolic constituents. J. Sci. Food Agri., 10: 63-68.

Williamson, E.M. (2002). Major Herbs of Ayurveda. China: Churchill-Livingstone, 312. 